information system still collects simple data. The press release that accompanies the Department of Health and Social Security's bulletin misleads when it suggests that activity represents quality. It does no such thing. The DHSS should be more aware of the need to measure effectiveness of health service activities to encourage improvement in the

Senior Lecturer in Epidemiology,

University of Wales College of Medicine, Cardiff CF4 4XN

1 Office of Population Censuses and Surveys. Hospital in-patient enquiry 1985. London: HMSO, 1987. (Series MB4.)

2 Jones J. Readmission rates. Lancet 1985; 1335.

3 Victor CR, Vetter NJ. Early readmission of elderly to hospital. Age Ageing 1985;14:37-42.

4 Cochrane AL. Effectiveness and efficiency. London: Nuffield Provincial-Hospitals Trust, 1972.

5 Holland WW, ed. Evaluation of health care. Oxford: Oxford University Press, 1983.

6 Mather HG, Pearson NG, Read KLQ, et al. Acute myocardial infarction: home and hospital treatment. BrMed f 1971;iii:334-8.

7 Craven JL, Evans GA, Davenport PJ, et al. Evaluation of incentive spirometer in management of post operative pulmonary complications. Brf Surg 1974;61:793-7.

8 West RR, Henderson AH. Randomised multicentre trial of early mobilisation after uncomplicated myocardial infarction. Br Heart f 1979;42:381-5.

9 Vetter NJ, Jones DA, Victor CR. Effect of health visitors working with elderly patients in general practice: a randomised controlled trial. Br Med $\mathcal{F}$ 1984;288:369-72.

10 McLachlan G, ed. A question of quality? Road to assurance in medical care. London: Nuffield Provincial Hospitals Trust, 1974.

11 Duncan A. Quality assurance: what now and where next? Br Med f 1980;280:300-2

12 McIlwaine BM, Howat RCL, Dunn F, Macnaughton MC. The Scottish perinatal mortality survey. Br Med f 1979;ii:1103-6. quality of health care.

weight, so that they account for about one in five of all liveborn infants weighing under $1500 \mathrm{~g}$. At these low weights the mortality risks of multiple births are slightly lower than those of singletons. Nevertheless, the high proportion of multiple births among very low birthweight infants underlines the need to keep neonatal intensive care units sufficiently unoccupied to allow for sets of two or more sibs to be admitted at a time_-events which can impose a severe strain on even well staffed units.

One of the unanswered questions is why trends in birth prevalence have varied over time; in many countries rates of dyzygotic twinning fell between 1956 and 1980, and in Britain and elsewhere they have risen since thenparticularly for orders higher than twins. ${ }^{3}$ Much of this last feature may be attributable to the increasing use of fertility drugs and in vitro fertilisation. Whatever the reason, the combination of a rise in birth prevalence and a fall in mortality means that an increasing number of infants delivered at multiple births are surviving. ${ }^{3}$

The physical, mental, and financial strain on young parents of coping with two or more young babies, often with all the problems that preterm birth brings, must be substantial. It is good that a new survey is being launched to look into the long term effects of multiple births on both parents and children. ${ }^{9}$ Its results cannot fail to interest parents and professionals alike, and I hope that the response to the survey will be generous.

Eva Alberman

\section{Multiple births}

We know little about the causes of either monozygotic or dyzygotic twinning, although the causes of the latter are multifactorial and include a genetic element. Maternal age and parity, ethnic group, maternal nutrition, height, fecundity, and concentrations of follicle stimulating hormone have all been associated with the risk of dyzygotic twinning, the peak prevalence being in mothers in their 30 s, with the rates being highest in African and lowest in some Asian populations. ${ }^{1-3}$ The frequency of monozygotic twinning seems to be constant. The incidence at conception of multiple births may be much higher than that at birth, the loss of only one twin appearing to be more common than was originally thought. ${ }^{4}$

A family history of multiple births may also be associated with the occurrence of some chromosomal anomalies, possibly reflecting a familial tendency to errors of cell division. Independently it has been associated with neural tube defects in the same sibship. ${ }^{6}$ Certainly congenital malformations of most kinds are more common in multiple than single births, but this is probably a direct complication of the multiplicity.?

Whatever the causes the consequences of multiple births are substantial, with a definite rise in virtually all the complications of pregnancy and delivery, including preeclampsia, preterm labour, growth retardation, placental anomalies (particularly in monozygotic twins), and malpresentations, and a consequent increase in the rate of neonatal problems. ${ }^{2}$ The risk is less for dyzygotic twins, especially when one or both twins are girls, and for the first baby of a set delivered. ${ }^{8} \mathrm{~A}$ recent review found that in England and Wales the 2\% of all births which are multiple make up $9 \%$ of all perinatal deaths. ${ }^{3}$ This is largely due to the general shift downwards of the distribution of their birth
Professor of Clinical Epidemiology,

London Hospital,

London E1 1BB

1 Nylander PPS. The phenomenon of twinning. In: Barron SL, Thomson A, eds. Obstetrical epidemiology. London: Academic Press, 1983:143-65.

2 MacGillivray I. Twin pregnancy. In: Phillip EE, Barnes J, Newton M, eds. Obstetrics and gynaecology. London: William Heinemann Medical Books, 1986:248-53.

3 Botting B, Davies IM, Macfarlane A. Recent trends in the incidence of multiple births and their mortality. Arch Dis Child (in press).

4 Schneider L, Bessis R, Hajeri H, et al. Early detection of twin pregnancies with the use of charts of normal uterine height and waist measurement. In: Nance WE, Allen G, Parisi P, eds. Twin

5 Neilsen J. Twins in sibships of Klinefelter's syndrome. F Med Genet 1966;3:114-6.

6 Elwood JM, Elwood JH. Other associations with multiple pregnancy. In: Elwood JM, Elwood JH, eds. Epidemiology of anencephalus and spina bifida. Oxford: Oxford University Press, 1980: eds. Ep.

7 Myrianthopoulos NC. Congenital malformations: the contribution of twin studies. In: Summitt RL, Bergsma D, eds. Cell surface factors, immune deficiencies, twin studies. The National
Foundation-March of Dimes. Birth defects: original article series. New York: Liss, 1978;XIV:6a. Foundation-March of Dimes. Birth defects: original article series. New York: Liss, 1978;XIV:6a.
Butler NR, Alberman ED. The multiple births. In: Butler NR, Alberman ED, eds. Perinatal 8 Butler NR, Alberman ED. The multiple births. In: Butler
problems. Edinburgh: E and S Livingstone, 1968:122-40.

9 Office of Population Censuses and Surveys. Study of triplet and higher order births. London: OPCS, 1987. (Newsletter No 1.)

\section{Aspiration cytology of the thyroid}

Enlargement of the thyroid gland is a common problem. A survey from the north east of England reported a prevalence of palpable goitre of $15 \cdot 5 \%$, with solitary thyroid nodules being found in $3 \cdot 2 \%$ of women and $0 \cdot 8 \%$ of men. ${ }^{1}$ Similarly, in the United States of America clinically apparent nodules are present in $4-7 \%$ of adults. ${ }^{2}$ The development of goitre is a concern to both the patient and the doctor because of the fear that the swelling may be malignant. Most goitres, however, are benign, and even in solitary nodules selected for surgery on clinical grounds malignancy is found in only around $10 \%{ }^{2}$

The traditional approach to investigating a patient preresearch. Part C. Clinical studies. New York: Liss, 1978:143-6. 